\title{
Synthesis, Spectroscopic, Thermal Analyses and Biological Activity Evaluation of New Zirconium(IV) Solid Complexes with Bidentate Lomefloxacin
}

\section{W. H. El-Shwiniy* and S. A. Sadeek}

Department of Chemistry, Faculty of Science, Zagazig University, Zagazig, Egypt.

\begin{abstract}
OUR metal complexes of antibacterial agent lomefloxacin (LFX) with zirconium(IV) in the presence of aniline (An), pyridine (Py) and o-tolidine (o-Tol) as nitrogen donor molecules and dimethyl formamide (DMF) as oxygen donor molecule have been prepared and characterized with physicochemical and diverse spectroscopic techniques (IR, UV-Vis. and ${ }^{1} \mathrm{H}$ NMR spectroscopes) as well as thermal analysis. The deprotonated lomefloxacin complexes of $\mathrm{Zr}(\mathrm{IV})$ were isolated as solids with the general formula, $\left[\mathrm{ZrO}(\mathrm{LFX})_{2} \mathrm{~L}\right] \mathrm{Cl}_{2}$, where $\mathrm{L}=\mathrm{An}, \mathrm{Py}$, o-Tol and DMF. The infrared spectral data show the chelation behavior of LFX toward Zr(IV) through oxygen of pyridone, one oxygen of carboxylic group and complete the coordination number with nitrogen or oxygen atom of $\mathrm{L}$. The thermodynamic parameters are calculated from the thermal analysis curves using the Coats-Redfern and Horowitz-Metzger methods. The antibacterial of LFX and their Zr(IV) complexes were also evaluated for their antibacterial activity against three Gram (+Ve) and three Gram (-Ve) microorganisms.
\end{abstract}

Keywords: Lomefloxacin, Characterization, Complexes- antibacterial.

\section{Introduction}

The fluoroquinolones constitute an important class of synthetic antimicrobial agents. Lomefloxacin (Scheme 1) is member of the second generation fluoroquinolones antibiotics family, sold under the following brand names in
English speaking countries Maxaquin, Okacyn, Uniquin, transcriptase inhibitor and stable under ordinary conditions with color off-white to yellow crystals. The crystal structures of several free fluoroquinolones molecules have been determined [1-5].<smiles>[Z]C1CN(c2c(F)cc3c(=O)c(C(=O)[O-])c([2H])n([3H])c3c2F)CC[NH2+]1</smiles>

Scheme 1. Structure of lomefloxacin(1-ethyl-6,8-difluro-7-(3-methyl piperazine-1-yl)-4-oxoquinoline-3-carboxylic acid).

*Corresponding author e-mail: walaa1986@zu.edu.eg

Tel.: +20 01119462284; fax: +20 0553208213 .

DOI: 10.21608/EJCHEM.2018.3682.1323

C2017 National Information and Documentation Center (NIDOC) 
It is interesting to note that in most cases the carboxylic group is not deprotonated and the hydrogen atom of this group is hydrogen bonded to an adjacent 4-oxo atom. In a few examples, lomefloxacin, norfloxacin, moxifloxacin and ciprofloxacin, the carboxylic group is protonated and the molecule thus exists in a zwitterionic form with protonated terminal nitrogen of the piperazine ring in a solid state [6-9]. Crystal structures of fluoroquinolones complexes indicate that neutral fluoroquinolones in the zwitterionic state are capable of forming simple complexes and the mechanism of the interaction between fluoroquinolones and metal cations was chelation between the metal ions and the 4-oxo and adjacent carbonyl groups [10-15]. Since these functional groups are required for antibacterial activity the synthesis and characterization of new metal complexes with fluoroquinolones antibacterial agents are of great importance for understanding the drug-metal ion interaction and taking into account their potential pharmacological use [14-22].

The literature research has shown that no work is reported on LFX with $\mathrm{Zr}$ (IV)in the presence of aniline, pyridine, o-tolidine and dimethylformamide. We reported here the reaction of LFX with $\mathrm{Zr}(\mathrm{IV})$ and interpreting the nature of these interactions using the following techniques IR, UV-Vis, ${ }^{1} \mathrm{H}$ NMR, thermal analysis, elemental analysis, and molar conductivity. Also, the present work aimed to study the effect of changing L (An, Py, o-Tol and DMF) of LFX complexes in order to hopefully produce novel antibacterial inhibitors.

\section{Experimental}

\section{Materials}

All chemicals used for the preparation of the complexes were of analytical reagent grade, commercially available from different sources and used without further purification. Lomefloxacin was obtained from Merck Chemical Co. $\mathrm{ZrOCl}_{2} .6 \mathrm{H}_{2} \mathrm{O}(99.9 \%)$ and all solvents were purchased from Fluka Chemical Co.

\section{Synthesis of the complexes}

An ethanolic suspended solution $(20 \mathrm{~mL})$ of LFX (1.0 mmol, $0.388 \mathrm{~g}$ ) was added to an ethanolic solution of $\mathrm{ZrOCl}_{2} \cdot 6 \mathrm{H}_{2} \mathrm{O}(0.5 \mathrm{mmol}$, $0.143 \mathrm{~g})$. The reaction mixture was stirred at room temperature for $1 \mathrm{~h}$ and then adding $1 \mathrm{~mL}$ DMF $(0.5 \mathrm{mmol}, \mathrm{d}=0.949)$ after that the reaction mixture was stirred for 3 days at room temperature. The solution was left for slow evaporation, after that the white $\left[\mathrm{ZrO}(\mathrm{LFX})_{2} \mathrm{DMF}\right] \mathrm{Cl}_{2}$ product was deposited. The solid obtained was filtered under vacuum, washed with ethanol and dried over anhydrous $\mathrm{CaCl}_{2}$.

The chemical structures of the synthesized metal complexes were confirmed as follows:

$\left[\mathrm{ZrO}(\mathrm{LFX})_{2} \mathrm{DMF}_{2} \mathrm{Cl}_{2}\right.$

White; Yield: 65 \%; m.p.: 300-304 ${ }^{\circ} \mathrm{C}$; M.Wt:953.22; Elemental analysis for $\mathrm{ZrC}_{37} \mathrm{H}_{45} \mathrm{~N}_{7} \mathrm{O}_{8} \mathrm{~F}_{4} \mathrm{Cl}_{2}$ : found, $\mathrm{C} 46.53 \%, \mathrm{H} 4.74 \%$, $\mathrm{N} 10.23 \%$, M $9.53 \%$, Cl $7.42 \%$, Calc. C 46.58 \%, H $4.72 \%$, N $10.28 \%$, M $9.57 \%$, Cl $7.45 \%$; $\Lambda_{\mathrm{m}}=243.00 \mathrm{~S} \mathrm{~cm}^{2} \mathrm{~mol}^{-1}$, IR (KBr): $v=1616 \mathrm{vs}$ (asymmetric $\left.\mathrm{COO}^{-}\right), 1544 \mathrm{~m} \quad(\mathrm{C}=\mathrm{O}$, pyridone group), 1389s (symmetric $\left.\mathrm{COO}^{-}\right), 806 \mathrm{~s}(\mathrm{Zr}=\mathrm{O})$, 648ms, 622vw, 589vw (Zr-O). UV-Vis (solid reflectance): $\lambda=221,269 \mathrm{~nm} \pi-\pi^{*}$ transitions, $\lambda=$ $311,321 \mathrm{~nm} \mathrm{n}-\pi^{*}$ transitions, $\lambda=500 \mathrm{~nm}$ ligandmetal charge transfer. ${ }^{1} \mathrm{H}$ NMR $\left(\right.$ DMSO- $\left.\mathrm{d}_{6}\right): \delta$ $=1.16(1)\left(\mathrm{t}, 6 \mathrm{H},-\mathrm{CH}_{3}\right), 1.45$ (2) $\left(\mathrm{d}, 6 \mathrm{H},-\mathrm{CH}_{3}\right)$, $3.60\left(\mathrm{~s}, 6 \mathrm{H},-\mathrm{CH}_{3}\right.$; DMF), 3.98 (4) (m, 1H, $\left.-\mathrm{CH}\right)$, $3.61,4.10(3,5)\left(\mathrm{t}, 4 \mathrm{H},-\mathrm{CH}_{2}\right), 4.17$ (6) $(\mathrm{d}, 2 \mathrm{H}$, $\left.-\mathrm{CH}_{2}\right), 4.62$ (7) (q, 2H, $\left.-\mathrm{CH}_{2}\right), 9.49$ (8) (s, 4H, $\left.{ }^{+} \mathrm{NH}_{2}\right), 7.34-7.88(9,10)(\mathrm{s}, 4 \mathrm{H}, \mathrm{H}-\mathrm{Ar}), 8.2$ (s, $1 \mathrm{H}, \mathrm{H}-\mathrm{C}=\mathrm{O}$; DMF).

$\left[\mathrm{ZrO}(\mathrm{LFX})_{2} \mathrm{An}\right] \mathrm{Cl}_{2}$

Brown; Yield: 70 \%; m.p.: 254-257 ${ }^{\circ} \mathrm{C}$; M.Wt:973.22; Elemental analysis for $\mathrm{ZrC}_{40} \mathrm{H}_{45} \mathrm{~F}_{4} \mathrm{~N}_{7} \mathrm{O}_{7} \mathrm{Cl}_{2}$ : found, $\mathrm{C} 49.29 \%, \mathrm{H} 4.58 \%$, $\mathrm{N} 10.03 \%$, M $9.33 \%$, Cl 7.27\%, Calc. C 49.32\%, H $4.62 \%$, N $10.07 \%$, M $9.37 \%$, Cl $7.30 \%$; $\Lambda_{\mathrm{m}}=263.04 \mathrm{~S} \mathrm{~cm}^{2} \mathrm{~mol}^{-1}$; IR (KBr): $v=1616 \mathrm{vs}$ (asymmetric $\left.\mathrm{COO}^{-}\right), 1556 \mathrm{w} \quad(\mathrm{C}=\mathrm{O}$, pyridine group), $1381 \mathrm{w}$ (symmetric $\left.\mathrm{COO}^{-}\right), 810 \mathrm{~ms}$ $(\mathrm{Zr}=\mathrm{O}), 656 \mathrm{vw}, 613 \mathrm{~ms}(\mathrm{Zr}-\mathrm{O}), 544 \mathrm{vw}(\mathrm{M}-\mathrm{N})$. UV-Vis (solid reflectance): $\lambda=222,254,295 \mathrm{~nm}$ $\pi-\pi^{*}$ transitions, $\lambda=324,389 \mathrm{~nm} \mathrm{n}-\pi^{*}$ transitions, $\lambda=495 \mathrm{~nm}$ ligand-metal charge transfer. ${ }^{1} \mathrm{H}$ NMR $\left(\mathrm{DMSO}_{6} \mathrm{~d}_{6}\right): \delta=1.16$ (1) (t, $\left.6 \mathrm{H},-\mathrm{CH}_{3}\right), 1.89$ (2) $\left(\mathrm{d}, 6 \mathrm{H},-\mathrm{CH}_{3}\right), 3.83$ (4) (m, 1H, $\left.-\mathrm{CH}\right), 3.61,4.10$ $(3,5)\left(\mathrm{t}, 4 \mathrm{H},-\mathrm{CH}_{2}\right), 4.17(6)\left(\mathrm{d}, 2 \mathrm{H},-\mathrm{CH}_{2}\right), 4.62$ (7) $\left(\mathrm{q}, 2 \mathrm{H},-\mathrm{CH}_{2}\right), 5.32\left(\mathrm{~s}, 2 \mathrm{H},-\mathrm{NH}_{2} ; \mathrm{An}\right), 6.63-$ 7.20 (s, 5H, H - Ar, An), 9.92 (8) (s, 4H, $\left.-{ }^{+} \mathrm{NH}_{2}\right)$, 7.52-7.88 $(9,10)(\mathrm{s}, 4 \mathrm{H}, \mathrm{H}-\mathrm{Ar})$.

$\left[\mathrm{ZrO}(\mathrm{LFX})_{2} \mathrm{Py}\right] \mathrm{Cl}_{2}$

White; Yield: $70 \%$; m.p.: $248-251{ }^{\circ} \mathrm{C}$; M.Wt: 959.22; Elemental analysis for $\mathrm{ZrC}_{39} \mathrm{H}_{43} \mathrm{~F}_{4} \mathrm{~N}_{7} \mathrm{O}_{7} \mathrm{Cl}_{2}$ : found, C $48.75 \%$, H $4.45 \%$, N $10.19 \%$, M 9.53 $\%, \mathrm{Cl} 7.36 \%$, Calc. C $48.79 \%$, H $4.48 \%$, N 10.22 $\%, \mathrm{M} 9.48 \%, \mathrm{Cl} 7.40 \% ; \Lambda_{\mathrm{m}}=238.12 \mathrm{~S} \mathrm{~cm}^{2} \mathrm{~mol}^{-1}$, IR (KBr): $v=1620 \mathrm{vs}$ (asymmetric $\mathrm{COO}^{-}$), $1533 \mathrm{~m}$ $(\mathrm{C}=\mathrm{O}$, pyridone group), $1389 \mathrm{~ms}$ (symmetric 
$\left.\mathrm{COO}^{-}\right), 810 \mathrm{~ms}(\mathrm{Zr}=\mathrm{O}), 667 \mathrm{~m}, 652 \mathrm{vw}(\mathrm{Zr}-\mathrm{O})$, $544 \mathrm{~m}(\mathrm{M}-\mathrm{N})$. UV-Vis (solid reflectance): $\lambda=230$ $\mathrm{nm} \pi-\pi^{*}$ transitions, $\lambda=303 \mathrm{~nm} \mathrm{n}-\pi^{*}$ transitions, $\lambda$ $=503 \mathrm{~nm}$ ligand - metal charge transfer. ${ }^{1} \mathrm{H}$ NMR $($ DMSO-d $): \delta=1.22$ (1) $\left(\mathrm{t}, 6 \mathrm{H},-\mathrm{CH}_{3}\right), 1.45$ (2) $\left(\mathrm{d}, 6 \mathrm{H},-\mathrm{CH}_{3}\right), 3.40$ (4) $(\mathrm{m}, 1 \mathrm{H},-\mathrm{CH}), 3.61$, $4.10(3,5)\left(\mathrm{t}, 4 \mathrm{H},-\mathrm{CH}_{2}\right), 4.17$ (6) (d, 2H, $\left.-\mathrm{CH}_{2}\right)$, 4.62 (7) (q, 2H, $-\mathrm{CH}_{2}$ ), 7.38-7.75 (s, 5H, H -Ar, Py), 8.98 (8) (s, 4H, $\left.-{ }^{+} \mathrm{NH}_{2}\right), 7.25-7.90(9,10)(\mathrm{s}$, $4 \mathrm{H}, \mathrm{H}-\mathrm{Ar})$.

\section{$\left[\mathrm{ZrO}(\mathrm{LFX})_{2} \mathrm{o}-\mathrm{Tol}\right] \mathrm{Cl}$}

Grey; Yield: 75 \%; m.p.: 298-304 ${ }^{\circ} \mathrm{C}$; M.Wt:1093.12; Elemental analysis for $\mathrm{ZrC}_{48} \mathrm{H}_{54} \mathrm{~N}_{8} \mathrm{O}_{7} \mathrm{~F}_{4} \mathrm{Cl}_{2}$ : found, C $52.64 \%, \mathrm{H} 4.85 \%$, N $10.15 \%$, M $8.23 \%$, Cl $6.40 \%$, Calc. C $52.74 \%$, $\mathrm{H} 4.98 \%$, N $10.25 \%, \mathrm{M} 8.35 \%, \mathrm{Cl} 6.49 \%$; $\Lambda_{\mathrm{m}}=$ $253.00 \mathrm{~S} \mathrm{~cm}^{2} \mathrm{~mol}^{-1}$; IR (KBr): $v=1620 \mathrm{~s}$ (asymmetric $\left.\mathrm{COO}^{-}\right), 1533 \mathrm{~m}(\mathrm{C}=\mathrm{O}$, pyridone group), 1396ms (symmetric $\left.\mathrm{COO}^{-}\right), 810 \mathrm{~ms}(\mathrm{Zr}=\mathrm{O}), 678 \mathrm{w}, 644 \mathrm{vw}$ (Zr-O), 533m (Zr-N). UV-Vis (solid reflectance): $\lambda=253 \mathrm{~nm} \pi-\pi^{*}$ transitions, $\lambda=312,321,333 \mathrm{~nm}$ $\mathrm{n}-\pi^{*}$ transitions, $\lambda=443 \mathrm{~nm}$ ligand-metal charge transfer. ${ }^{1} \mathrm{H}$ NMR (DMSO-d $\left.{ }_{6}\right): \delta=1.25$ (1) $(\mathrm{t}, 6 \mathrm{H}$, $\left.-\mathrm{CH}_{3}\right), 1.46(2)\left(\mathrm{d}, 6 \mathrm{H},-\mathrm{CH}_{3}\right), 3.51\left(\mathrm{~s}, 6 \mathrm{H},-\mathrm{CH}_{3}\right.$, o-Tol), $3.61(4)(\mathrm{m}, 1 \mathrm{H},-\mathrm{CH}), 3.61,4.10(3,5)(\mathrm{t}$, $\left.4 \mathrm{H},-\mathrm{CH}_{2}\right), 4.17$ (6) (d, 2H, $\left.-\mathrm{CH}_{2}\right), 4.62$ (7) (q, 2H, $\left.-\mathrm{CH}_{2}\right), 7.38-7.75$ (s, 8H, H-Ar, o-Tol), 9.15 (8) (s, $\left.4 \mathrm{H},{ }^{+} \mathrm{NH}_{2}\right), 7.20-7.91(9,10)(\mathrm{s}, 4 \mathrm{H}, \mathrm{H}-\mathrm{Ar})$.

\section{Instrumentation}

Elemental $\mathrm{C}, \mathrm{H}$ and $\mathrm{N}$ analysis was carried out on a Perkin Elmer CHN 2400. The percentage of the metal ions were determined gravimetrically by transforming the solid products into zirconium oxide, and also determined by using atomic absorption method. Spectrometer model PYEUNICAM SP 1900 fitted with the corresponding lamp was used for this purpose. IR spectra were recorded on FTIR 460 PLUS (KBr discs) in the range from 4000-400 $\mathrm{cm}^{-1},{ }^{1} \mathrm{H}$ NMR spectra were recorded on Varian Mercury VX300 NMR Spectrometer using DMSO-d $\mathrm{d}_{6}$ as solvent. TG-DTG measurements were carried out under $\mathrm{N}_{2}$ atmosphere within the temperature range from room temperature to $800^{\circ} \mathrm{C}$ (LFX) or $1000^{\circ} \mathrm{C}(\mathrm{Zr}(\mathrm{IV})$ complexes) using TGA-50H Shimadzu. Electronic spectra were obtained using UV-3101PC Shimadzu. The solid reflection spectra were recorded with $\mathrm{KBr}$ pellets. Molar conductivities of the solutions of the ligand and metal complexes in DMSO at $10^{-3} \mathrm{M}$ were measured on CONSORT K410. All measurements were carried out at ambient temperature with freshly prepared solutions.

\section{Antibacterial activity}

Antibacterial activity of LFX and $\mathrm{Zr}(\mathrm{IV})$ complexes was investigated by the agar well diffusion method. The activity of tested samples was studied against different bacterial species, such as Staphylococcus aureus ( $S$. aureus), Bacillis subtilis (B. subtilis) as gram positive bacteria and Escherichia coli (E. coli), Pseudomonas aeruginosa (P. aeruginosa) as gram negative bacteria. The tested microorganisms isolates were isolated from Egyptian soil and identified according to the standard mycological and bacteriological keys for identification of bacteria as stock cultures in the regional center for mycology and biotechnology, Al-Azhar University. The solution of $5 \mathrm{mg} / \mathrm{mL}$ of each compound in DMSO was prepared for testing against bacteria. Centrifuged pellets of bacteria from a $24 \mathrm{~h}$ old culture containing approximately 104-106 CFU (colony forming unit) per $\mathrm{ml}$ were spread on the surface of nutrient agar $(1 \%$ Peptone, $0.5 \%$ Yeast extract, $0.5 \% \mathrm{NaCl}, 1.0 \%$ Agar and $1000 \mathrm{~mL}$ of distilled water, $\mathrm{PH} 7.0$ ) which was autoclaved under $121^{\circ} \mathrm{C}$ for at least 20 min. wells were created in medium with the help of sterile metallic bores and then cooled down to $47^{\circ} \mathrm{C}$. The activity was determined by measuring the diameter of the inhibition zone (in $\mathrm{mm}$ ). 100 $\mu \mathrm{L}$ of the tested samples $(10 \mathrm{mg} / \mathrm{mL})$ were loaded into the wells of the plates. All compounds were prepared in DMSO which was loaded as control. The plates were kept for incubation at $37{ }^{\circ} \mathrm{C}$ for $24 \mathrm{~h}$ and then the plates were examined for the formation of zone of inhibition.

\section{$\underline{\text { Results and Discussion }}$}

The new synthesized lomefloxacinates of $\mathrm{Zr}$ (IV) complexes were characterized through elemental analysis, IR, UV-Vis, ${ }^{1} \mathrm{H}$ NMR, melting point, molar conductivity, as well as thermogravimetric analysis. In these complexes LFX acts as neutral bidentate ligand bound to $\mathrm{Zr}(\mathrm{IV})$ through the pyridone oxygen and one carboxylate oxygen. The proposed formulas of the complexes agree well with their from the elemental analysis. The molar conductivity value for LFX in DMSO-d ${ }_{6}$ solvent at $1.0 \times 10^{-3} \mathrm{M}$ was at $20.01 \mathrm{~S}$ $\mathrm{cm}^{2} \mathrm{~mol}^{-1}$, but the molar conductivity values for its complexes were in the range from 263.04 to 238.00 $\mathrm{S} \mathrm{cm}^{2} \mathrm{~mol}^{-1}$. All the measurements are in the range suggesting them to be electrolytes nature [23]. The isolated solid complexes are with the general formula: $\left.\mathrm{ZrO}(\mathrm{LFX})_{2} \mathrm{DMF}\right] \mathrm{Cl}_{2}, \quad\left[\mathrm{ZrO}(\mathrm{LFX})_{2} \mathrm{An}\right]$ $\mathrm{Cl}_{2}, \quad\left[\mathrm{ZrO}(\mathrm{LFX})_{2} \mathrm{Py}\right] \mathrm{Cl}_{2}$ and $\left[\mathrm{ZrO}(\mathrm{LFX})_{2} \mathrm{O}-\mathrm{Tol}\right]$ 
$\mathrm{Cl}_{2}$. The brown, white and grey solid complexes $\left[\mathrm{ZrO}(\mathrm{LFX})_{2} \mathrm{An}\right] \mathrm{Cl}_{2}, \quad\left[\mathrm{ZrO}(\mathrm{LFX})_{2} \mathrm{Py}\right] \mathrm{Cl}_{2}$ and $\left[\mathrm{ZrO}(\mathrm{LFX})_{2} \mathrm{O}-\mathrm{Tol}\right] \mathrm{Cl}_{2}$ were prepared in a similar manner described above by using An, Py, o-Tol and DMF, respectively, instead of DMF in 1:2:1 (Zr(IV):LFX:L)(L = An, Py, o-Tol and DMF) molar ratio. Single crystal suitable for X-ray crystallographic measurements was not obtained The complexes are stable in their solid case at room temperature and their integrity in solution state were good and stable enough within 3 weeks (in DMSO- $\mathrm{d}_{6}$ and DMF solvents) considering that we have used these solutions during that time to measure molar conductivity, antibacterial activity and ${ }^{1} \mathrm{H}$ NMR spectra.

\section{Infrared spectra}

IR spectra have proven to be the most suitable technique to give enough information to elucidate the way of bonding of LFX to the metal ions, in the absence of a powerful technique. The IR spectra of LFX and $\mathrm{Zr}(\mathrm{IV})$ complexes were carried out in the region of $4000-400 \mathrm{~cm}^{-1}$ (Fig.S1). The strong band observed at $1618 \mathrm{~cm}^{-1}$ in LFX is assigned to the carbonyl stretching vibration $v(\mathrm{C}=\mathrm{O})[16$, 17]. This band is shifted to a lower value in the spectra of complexes indicating the participation of the carbonyl oxygen atom in coordination. Coordination with metal ions via the carboxylate oxygen atom is indicated by appearance of $v_{\text {as }}\left(\mathrm{COO}^{-}\right)$and $v_{\mathrm{s}}\left(\mathrm{COO}^{-}\right)$stretching vibration bands around $1618 \mathrm{~cm}^{-1}$ and $1388 \mathrm{~cm}^{-1}$, respectively, in the complexes. The $\Delta v\left(224-235 \mathrm{~cm}^{-1}\right)$ indicates the presence of monodentate carboxylate group [24,25]. New bands are found in the spectra of the complexes in the regions $678-515 \mathrm{~cm}^{-1}$ which can be assigned to $v(\mathrm{Zr}-\mathrm{O})$ and $v(\mathrm{Zr}-\mathrm{N})$.

Some bands showed significant shifts in all complexes, although these groups did not participate in the bonding to metal ions. These bands are the $v(\mathrm{C}=\mathrm{C}), v(\mathrm{C}-\mathrm{N}), v(\mathrm{C}-\mathrm{C}), v(\mathrm{C}-\mathrm{H})$ stretch in $\mathrm{CH}_{3}$ and in $\mathrm{CH}_{2}$ groups and the benzene and pyridine rings stretching vibrations. These bands are either shifted to lower or higher frequencies. This shift is attributed to the change in the environment around these atoms as the results of coordination of LFX to metal ion [16]. The data given in Fig.S1 showed that $v(\mathrm{Zr}=\mathrm{O})$ is a strong band at $806 \mathrm{~cm}^{-1}$.

Therefore, it is concluded from the IR spectra that LFX behaves as neutral bidentate ligand coordinated to the metal ion via pyridone oxygen atom and the protonated carboxylate oxygen in accordance with the previously published data on similar types of fluoroquinolone drugs [14-17].

The proposed structure of $\mathrm{Zr}(\mathrm{IV})$ complexes according to the above data is shown in Scheme 2:

\section{Electronic reflection spectra}

UV-Visible spectral data of LFX and Zr(IV)

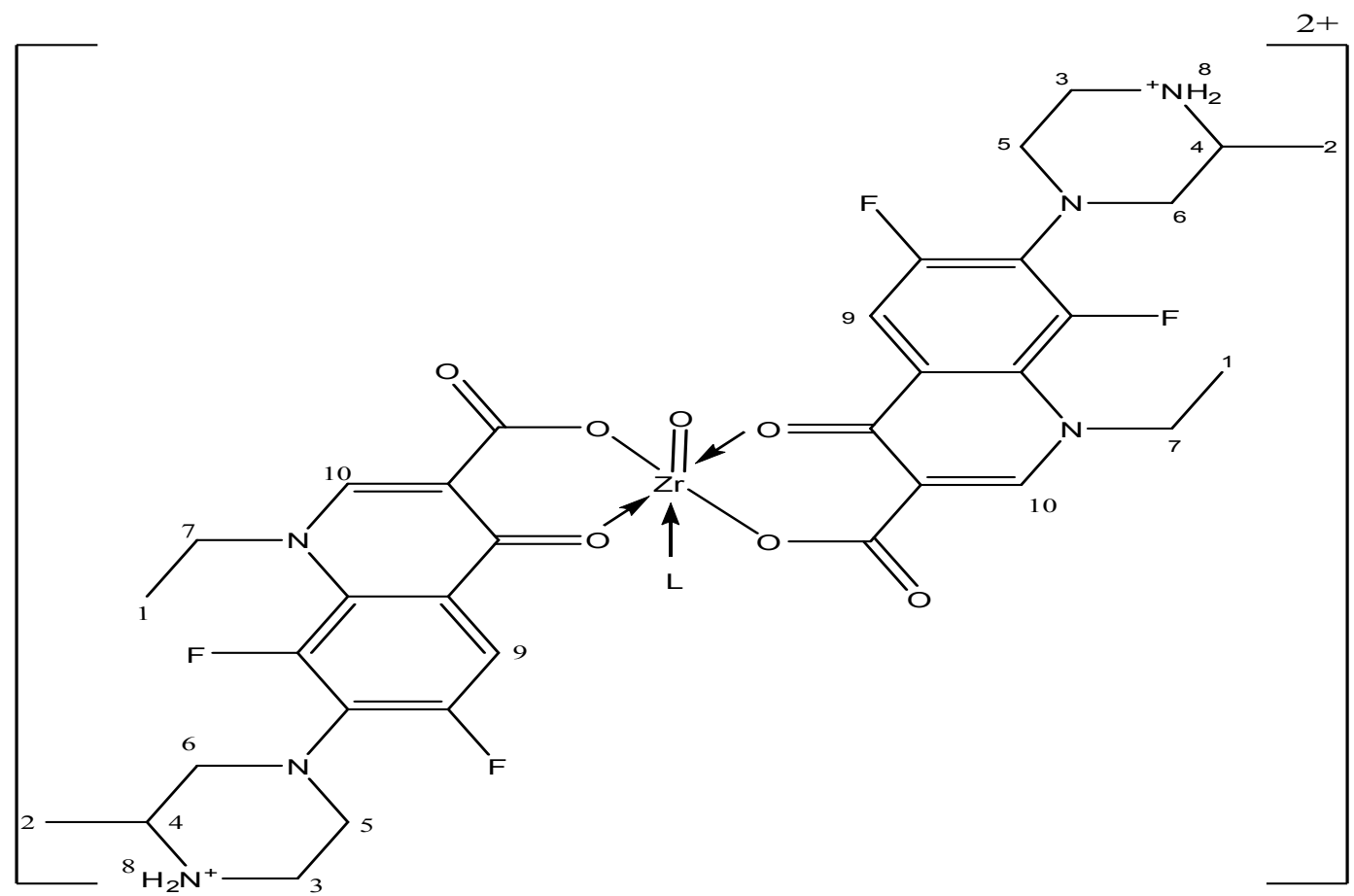

Scheme 2. The coordination mode of $\mathrm{Zr}(\mathrm{IV})$ with $\mathrm{LFX}$ and $\mathrm{L}$ (L = DMF, An, Py and o-Tol). 
chelates have been recorded as electronic solid reflection spectra ranging from 200- $800 \mathrm{~nm}$ (Fig. S2). Free LFX showed three bands at 214, 298 and $304 \mathrm{~nm}$. These bands may be attributed to $\pi-\pi^{*}$ and $n-\pi^{*}$ transitions inside the lomefloxacin molecule which shifted in $\mathrm{Zr}$ (IV) complexes at 221-443 $\mathrm{nm}$. Also, these complexes exhibit a ligand-metal charge transfer bands at 443-503 $\mathrm{nm}$ [16].

\section{The ${ }^{1} H$ NMR spectra}

To create harmony between the parts of the study, we embodied the ${ }^{1}$ HNMR spectra of LFX and $\mathrm{Zr}$ (IV) complexes (Fig.1). The ${ }^{1} \mathrm{H}$ NMR spectra of the compounds isolated from systems containing quinolones and metal [23,24]; minor shifts were found. Small shifts could be due to the change in the counter anion or to a different association of the quinolone molecules. On comparing main signals of LFX with its complexes, it is observed that all the signals of the free ligand are present in the spectra of the complexes with chemical shift upon binding of ligand to $\mathrm{Zr}(\mathrm{IV})$ [25].

The ${ }^{1} \mathrm{H}$ NMR spectrum of LFX showed signals at $\delta=1.31(1)\left(\mathrm{t}, 3 \mathrm{H},-\mathrm{CH}_{3}\right), 1.71(2)(\mathrm{d}, 3 \mathrm{H}$, $\left.-\mathrm{CH}_{3}\right), 3.98(4)(\mathrm{m}, 1 \mathrm{H},-\mathrm{CH}), 3.61,4.10(3,5)(\mathrm{t}$, $\left.4 \mathrm{H},-\mathrm{CH}_{2}\right), 4.17(6)\left(\mathrm{d}, 2 \mathrm{H},-\mathrm{CH}_{2}\right), 4.62$ (7) (q, 2H, $\left.-\mathrm{CH}_{2}\right), 8.95(8)\left(\mathrm{s}, 2 \mathrm{H},-{ }^{+} \mathrm{NH}_{2}\right), 7.0,7.78(9,10)$ (s, 2H, H -Ar). The ${ }^{1} \mathrm{H}$ NMR data for the prepared solid complexes are with small shifts for all other signals are shown, thus showing that the magnetic environment of the aromatic rings has changed significantly with coordination.

\section{Thermal analysis}

The thermal behaviour of LFX and their metal complexes have been studied by thermogravimetric analysis (TGA) and differential thermogravimetric (DTG) which carried out under nitrogen atmosphere and rate flow of $20 \mathrm{~mL} \mathrm{~min}^{-1}$. Figure 2 represents the TGA and DTG curves for $\mathrm{Zr}$ (IV) complexes while the maximum temperature values for decomposition along with the corresponding weight loss values for each step of the decomposition reaction are given in Table 1. The LFX was thermally stable in the temperature range 25-250 C. Decomposition of the lomefloxacin started at $250^{\circ} \mathrm{C}$ and finished at $600{ }^{\circ} \mathrm{C}$ with one stage at two maxima 319 and $553{ }^{\circ} \mathrm{Cand}$ is accompanied by a weight loss of 99.95\%.

The $\quad\left[\mathrm{ZrO}(\mathrm{LFX})_{2} \mathrm{DMF}\right] \mathrm{Cl}_{2} \quad$ complex started at $220{ }^{\circ} \mathrm{C}$ and finished at $958{ }^{\circ} \mathrm{C}$ with two decomposition steps, the first stage at a temperature maximum $333{ }^{\circ} \mathrm{C}$ accompanied by weight loss of $7.68 \%$ and may be attributed to the loss of DMF molecule [26] which is in good agreement with the calculated values of $7.66 \%$. The second stage at a temperature maximum 546 ${ }^{\circ} \mathrm{C}$ accompained by weight loss of $66.69 \%$ and giving the final product as $\mathrm{ZrO}_{2}+10 \mathrm{C}$ [27].
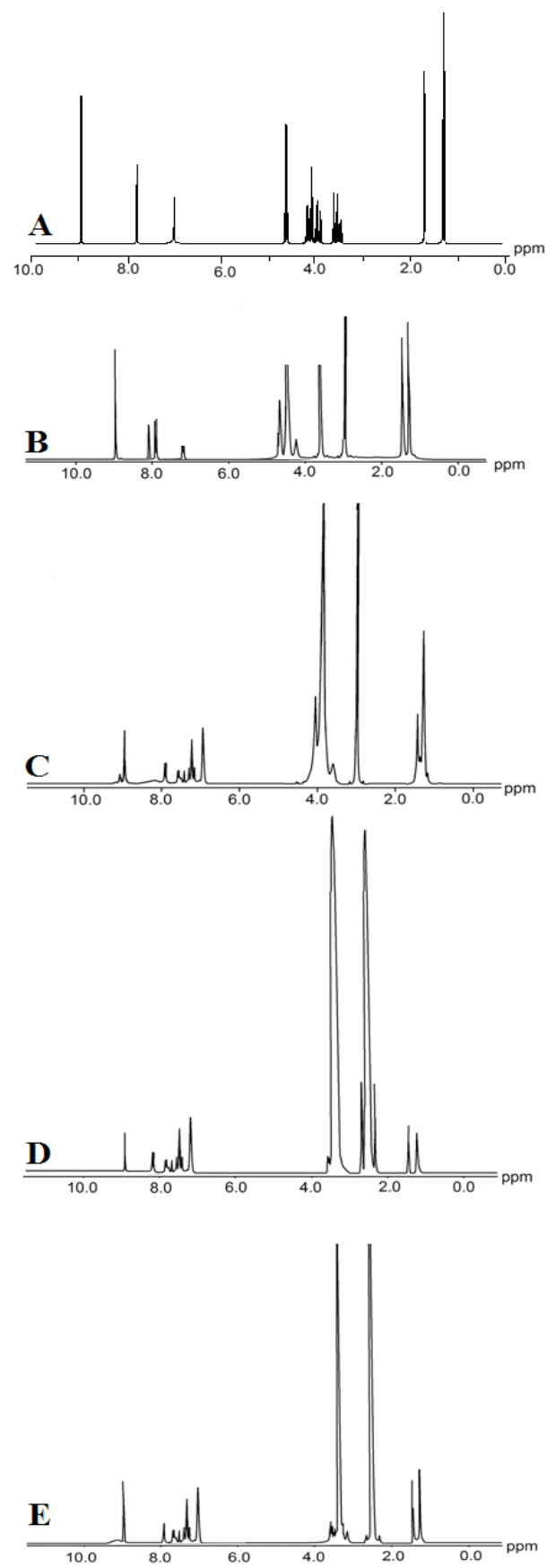

Fig. 1. ${ }^{1} \mathrm{H}$ NMR spectra for (A) LFX, (B) $\left[\mathrm{ZrO}(\mathrm{LFX})_{2} \mathrm{DMF}\right] \mathrm{Cl}_{2}$, (C) $\left[\mathrm{ZrO}(\mathrm{LFX})_{2} \mathrm{An}\right] \mathrm{Cl}$, (D) $\left[\mathrm{ZrO}(\mathrm{LFX})_{2} \mathrm{Py}_{\mathrm{Cl}} \mathrm{Cl}_{2}\right.$ and (E) $\left[\mathrm{ZrO}(\mathrm{LFX})_{20}-\right.$ $\mathrm{Tol}_{\mathrm{Cl}} \mathrm{Cl}_{2}$ in DMSO-d 6 , $\boldsymbol{\delta}_{\mathrm{TMS}}$.

Egypt.J.Chem. Special Issue (2018) 

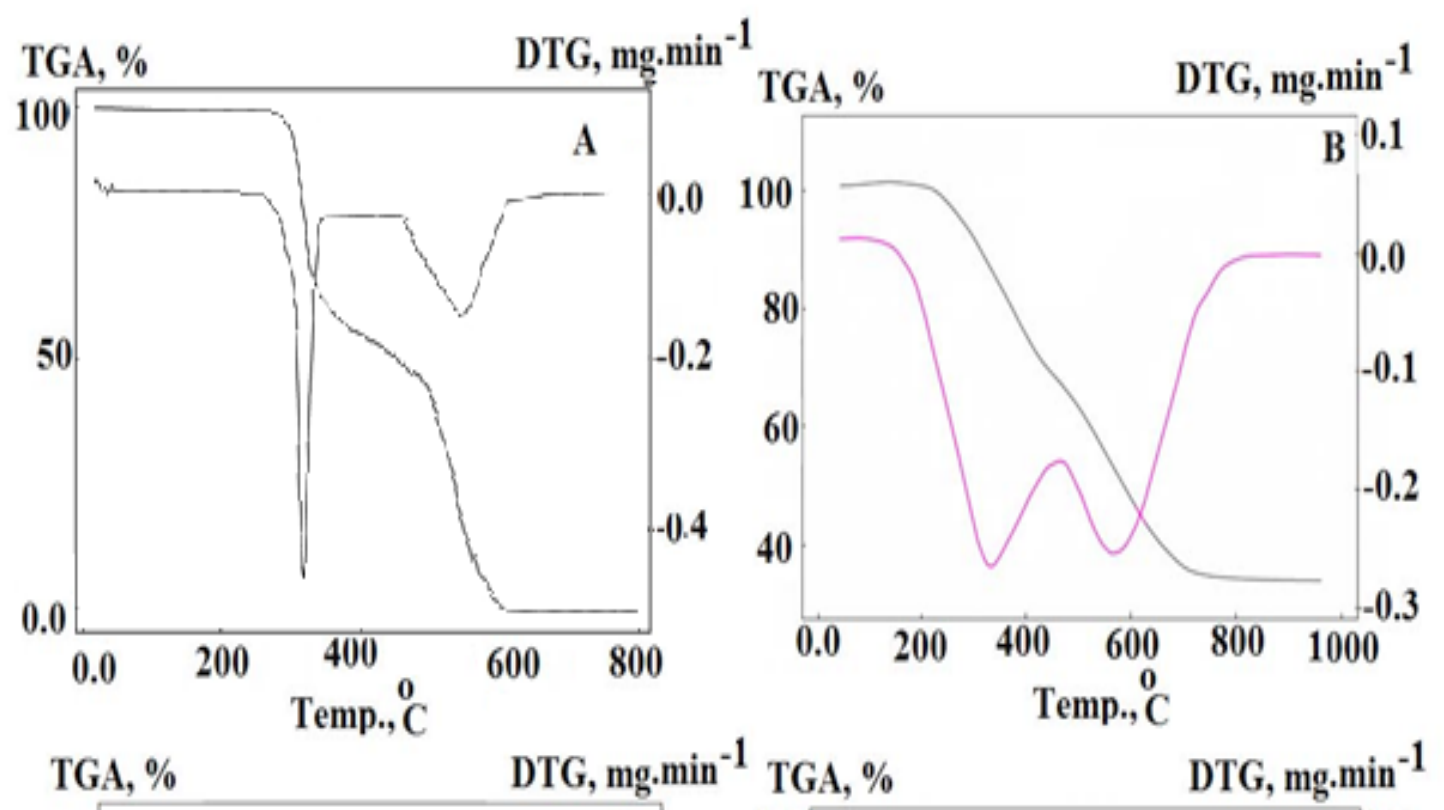

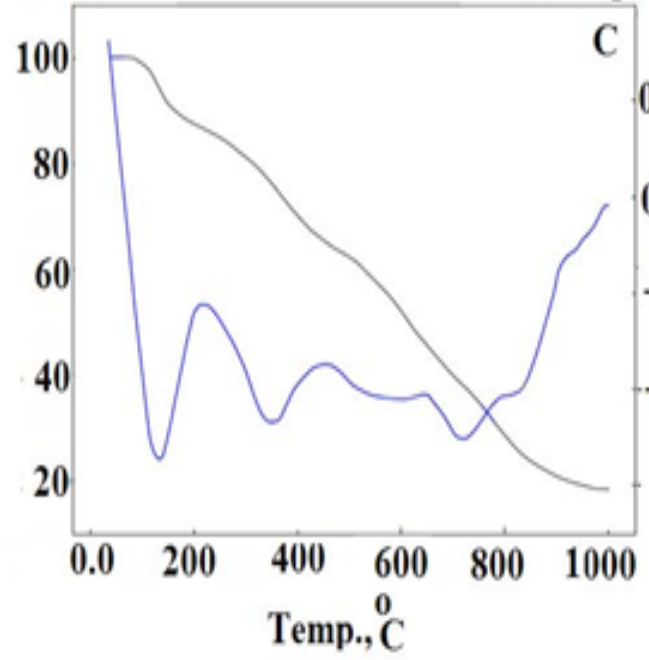

TGA, \%

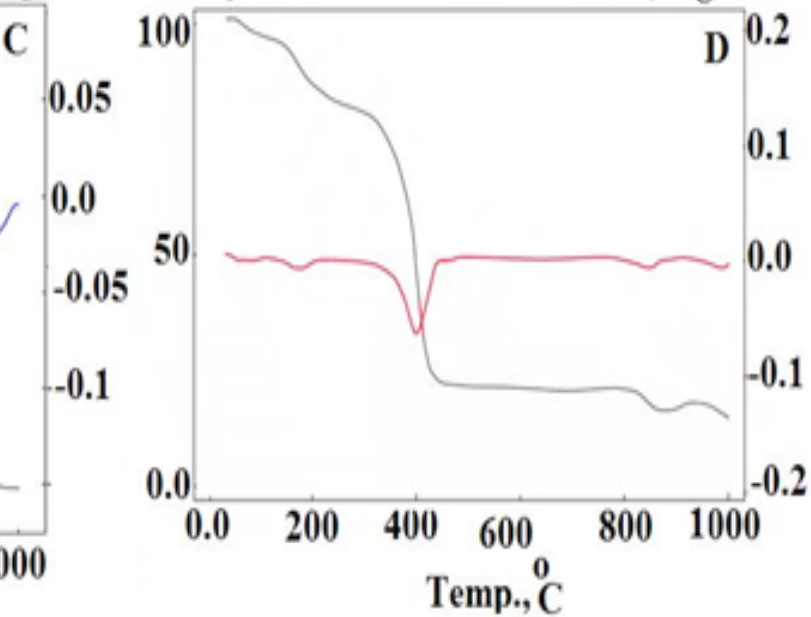

DTG, mg.min ${ }^{-1}$

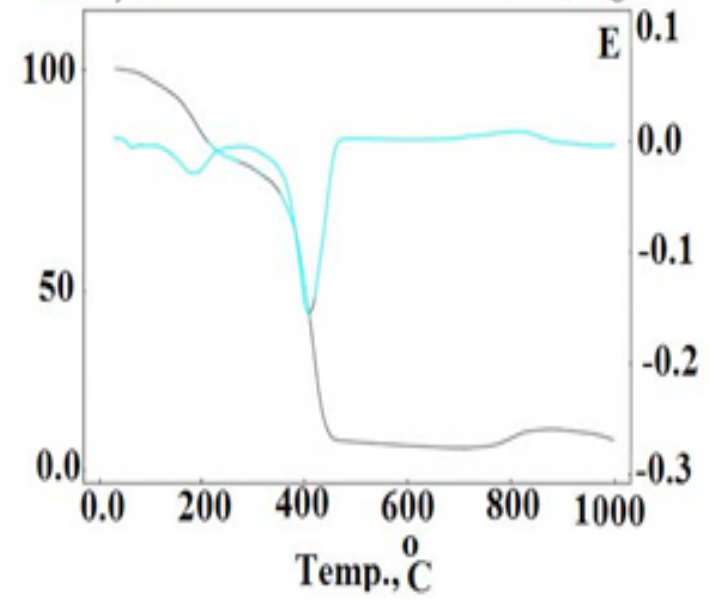

Fig. 2. TGA and DTG diagrams for (A) LFX, (B) $\left[\mathrm{ZrO}(\mathrm{LFX})_{2} \mathrm{DMF}_{C} \mathrm{Cl}_{2},(\mathrm{C})\left[\mathrm{ZrO}(\mathrm{LFX})_{2} \mathrm{An}\right] \mathrm{Cl}{ }_{2},(\mathrm{D})\left[\mathrm{ZrO}(\mathrm{LFX})_{2} \mathrm{Py}\right]\right.$ $\mathrm{Cl}_{2}$ and $(\mathrm{E})\left[\mathrm{ZrO}(\mathrm{LFX})_{20}-\mathrm{Tol} \mathrm{Cl}_{2}\right.$ 
TABLE 1. The maximum temperature $T_{\max }\left({ }^{\circ} \mathrm{C}\right)$ and weight loss values of the decomposition stages for LFX and $\mathrm{Zr}$ (IV) complexes.

\begin{tabular}{|c|c|c|c|c|c|}
\hline \multirow{2}{*}{ Compounds } & \multirow{2}{*}{ Decomposition } & \multirow{2}{*}{$\mathbf{T}_{\max }\left({ }^{\circ} \mathrm{C}\right)$} & \multicolumn{2}{|c|}{$\begin{array}{c}\text { Weight loss } \\
(\%)\end{array}$} & \multirow[t]{2}{*}{ Lost species } \\
\hline & & & Calc. & Found & \\
\hline $\begin{array}{l}\text { LFX } \\
\left(\mathrm{C}_{17} \mathrm{H}_{20} \mathrm{~N}_{3} \mathrm{O}_{3} \mathrm{~F}_{2}\right)\end{array}$ & $\begin{array}{l}\text { First step } \\
\text { Total loss } \\
\text { Residue }\end{array}$ & 319,553 & $\begin{array}{l}100 \\
100,0.0\end{array}$ & $\begin{array}{c}99.99 \\
100,0.0\end{array}$ & $\begin{array}{l}6 \mathrm{C}_{2} \mathrm{H}_{2}+3 \mathrm{CO}+\mathrm{C}_{2} \mathrm{H}_{4}+ \\
2 \mathrm{HF}+0.5 \mathrm{H}_{2}+ \\
1.5 \mathrm{~N}_{2}\end{array}$ \\
\hline $\begin{array}{l}{\left[\mathrm{ZrO}(\mathrm{LFX})_{2} \mathrm{DMF}\right] \mathrm{Cl}_{2}} \\
\left(\mathrm{ZrC}_{37} \mathrm{H}_{45} \mathrm{~F}_{4} \mathrm{~N}_{7} \mathrm{O}_{8} \mathrm{Cl}_{2}\right)\end{array}$ & $\begin{array}{l}\text { First step } \\
\text { Second step } \\
\text { Total loss, } \\
\text { Residue }\end{array}$ & $\begin{array}{l}333 \\
546\end{array}$ & $\begin{array}{l}7.66 \\
66.83 \\
74.49 \\
25.51\end{array}$ & $\begin{array}{r}7.68 \\
66.69 \\
74.37 \\
25.63\end{array}$ & $\begin{array}{l}\mathrm{C}_{2} \mathrm{H}_{6}+\mathrm{CO}+0.5 \mathrm{~N}_{2}+0.5 \mathrm{H}_{2} \\
12 \mathrm{C}_{2} \mathrm{H}_{2}+4 \mathrm{HF}+2 \mathrm{HCl}+2 \mathrm{NH}_{3}+ \\
4 \mathrm{NO}+\mathrm{H}_{2} \mathrm{O} \\
\mathrm{ZrO}_{2}+10 \mathrm{C}\end{array}$ \\
\hline $\begin{array}{l}{\left[\mathrm{ZrO}(\mathrm{LFX})_{2} \mathrm{An}\right] \mathrm{Cl}_{2}} \\
\left(\mathrm{ZrC}_{40} \mathrm{H}_{45} \mathrm{~F}_{4} \mathrm{~N}_{7} \mathrm{O}_{7} \mathrm{Cl}_{2}\right)\end{array}$ & $\begin{array}{l}\text { First step } \\
\text { Second step } \\
\text { Total loss } \\
\text { Residue }\end{array}$ & $\begin{array}{l}132 \\
348,720\end{array}$ & $\begin{array}{l}9.56 \\
70.38 \\
79.94 \\
20.06\end{array}$ & $\begin{array}{r}9.59 \\
70.28 \\
79.87 \\
20.13\end{array}$ & $\begin{array}{l}3 \mathrm{C}_{2} \mathrm{H}_{2}+0.5 \mathrm{~N}_{2}+0.5 \mathrm{H}_{2} \\
14 \mathrm{C}_{2} \mathrm{H}_{2}+4 \mathrm{HF}+2 \mathrm{HCl}+\mathrm{NH}_{3}+ \\
5 \mathrm{NO}+0.5 \mathrm{H}_{2} \\
\mathrm{ZrO}_{2}+6 \mathrm{C}\end{array}$ \\
\hline $\begin{array}{l}{\left[\mathrm{ZrO}(\mathrm{LFX})_{2} \mathrm{Py}\right] \mathrm{Cl}_{2}} \\
\left(\mathrm{ZrC}_{39} \mathrm{H}_{43} \mathrm{~F}_{4} \mathrm{~N}_{7} \mathrm{O}_{7} \mathrm{Cl}_{2}\right)\end{array}$ & $\begin{array}{l}\text { First step } \\
\text { Second step } \\
\text { Total loss } \\
\text { Residue }\end{array}$ & $\begin{array}{l}167,400 \\
842\end{array}$ & $\begin{array}{l}8.24 \\
76.42 \\
84.66 \\
15.34\end{array}$ & $\begin{array}{r}8.26 \\
76.32 \\
84.58 \\
15.42\end{array}$ & $\begin{array}{l}2.5 \mathrm{C}_{2} \mathrm{H}_{2}+0.5 \mathrm{~N}_{2} \\
16 \mathrm{C}_{2} \mathrm{H}_{2}+4 \mathrm{HF}+2 \mathrm{HCl}+5 \mathrm{NO}+ \\
0.5 \mathrm{~N}_{2} \\
\mathrm{ZrO}_{2}+2 \mathrm{C}\end{array}$ \\
\hline $\begin{array}{l}{\left[\mathrm{ZrO}(\mathrm{LFX})_{2} \mathrm{O}-\mathrm{Tol}\right] \mathrm{Cl}_{2}} \\
\left(\mathrm{ZrC}_{41} \mathrm{H}_{47} \mathrm{~F}_{4} \mathrm{~N}_{7} \mathrm{O}_{7} \mathrm{Cl}_{2}\right)\end{array}$ & $\begin{array}{l}\text { First step } \\
\text { Second step } \\
\text { Total loss } \\
\text { Residue }\end{array}$ & $\begin{array}{l}71,183 \\
412\end{array}$ & $\begin{array}{l}10.84 \\
71.82 \\
82.66 \\
17.34\end{array}$ & $\begin{array}{l}10.86 \\
71.33 \\
82.19 \\
17.81\end{array}$ & $\begin{array}{l}3.5 \mathrm{C}_{2} \mathrm{H}_{2}+\mathrm{H}_{2}+0.5 \mathrm{~N}_{2} \\
15 \mathrm{C}_{2} \mathrm{H}_{2}+4 \mathrm{HF}+2 \mathrm{HCl}+5 \mathrm{NO}+ \\
\mathrm{H}_{2}+0.5 \mathrm{~N}_{2} \\
\mathrm{ZrO}_{2}+4 \mathrm{C}\end{array}$ \\
\hline
\end{tabular}

The thermal decomposition of $\left[\mathrm{ZrO}(\mathrm{LFX})_{2} \mathrm{An}\right]$ $\mathrm{Cl}_{2}$ complex exhibits two main degradation steps. The first step of decomposition occurs from 50 to $219{ }^{\circ} \mathrm{C}$ at temperature maximum of $132{ }^{\circ} \mathrm{C}$ is accompanied by a weight loss of $9.59 \%$ in agreement with the theoretical values $9.56 \%$ for the loss of An molecule. The second step of decomposition occurs at two maxima 348 and 720 ${ }^{\circ} \mathrm{C}$ with a weight loss of $70.28 \%$, giving the final product as $\mathrm{ZrO}_{2}+6 \mathrm{C}$.
For $\left[\mathrm{ZrO}(\mathrm{LFX})_{2} \mathrm{Py}\right] \mathrm{Cl}_{2}$ complex the thermal decomposition exhibits two main degradation steps. The first step of decomposition occurs from 35 to $478{ }^{\circ} \mathrm{C}$ with two maxima of 167 and 400 ${ }^{\circ} \mathrm{C}$ is accompanied by a weight loss of $8.26 \%$ in agreement with the theoretical values $8.24 \%$ for the loss of Py molecule [21]. The second step of decomposition occurs at temperature maximum $842{ }^{\circ} \mathrm{C}$ with a weight loss of $76.32 \%$, giving the final product as $\mathrm{ZrO}_{2}+2 \mathrm{C}$. 
The thermal decomposition of $\left[\mathrm{ZrO}(\mathrm{LFX})_{2} \mathrm{O}-\right.$ Tol] $\mathrm{Cl}_{2}$ complex exhibits two main degradation steps. The first step of decomposition occurs from 47 to $260{ }^{\circ} \mathrm{C}$ with two maxima at 71 and $183{ }^{\circ} \mathrm{C}$ is accompanied by a weight loss of $10.86 \%$ in agreement with the theoretical values $10.84 \%$ for the loss of o-Tol molecule. The second step of decoms position occurs at temperature maximum of 412 ${ }^{\circ} \mathrm{C}$ with a weight loss of $71.33 \%$ and giving the final product as $\mathrm{ZrO}_{2}+4 \mathrm{C}$.

\section{The kinetics data}

The kinetic thermodynamic parameters such as activation energies, $E^{*}$, enthalpies, $\Delta H^{*}$, entropies, $\Delta \mathrm{S}^{*}$ and Gibbs free energies, $\Delta \mathrm{G}^{*}$, of the decomposition were evaluated graphically by employing the Coats-Redfern (CR) relationship [28]:

$$
\ln \left\lceil\frac{-\ln (1-\alpha)}{T^{2}}\right\rceil=\frac{-E^{*}}{R T}+\ln \left[\frac{A R}{\varphi E^{*}}\right]
$$

Where $\alpha$ and $\varphi$ are the fraction of the sample decomposed at time $t$ and the linear heating rate, respectively. $\mathrm{R}$ is the gas constant and $\mathrm{E}^{*}$ is the energy of activation in $\mathrm{kJ} \mathrm{mol}^{-1}$ and calculated from the slope and $\mathrm{A}$ in $\left(\mathrm{s}^{-1}\right)$ from the intercept. A plot of left-hand side (LHS) against $1 / T$ was drawn using origin 6.0 program and the fit line is produced (Fig. S3). With information of R, A and $\varphi$, the enthalpy of activation, $\Delta \mathrm{H}^{*}$, and Gibbs free energy, $\Delta \mathrm{G}^{*}$, the entropy of activation $\Delta \mathrm{S}^{*}$ in $(\mathrm{J}$ $\mathrm{K}^{-1} \mathrm{~mol}^{-1}$ ), were calculated (Table 2 ) via the equaq tions:

$$
\begin{gathered}
\Delta \mathrm{H}^{*}=\mathrm{E}^{*}-\mathrm{RT} \\
\Delta \mathrm{G}^{*}=\Delta \mathrm{H}^{*}-\mathrm{T} \Delta \mathrm{S}^{*} \\
\Delta \mathrm{S}^{*}=\mathrm{R} \ln \left(\frac{\mathrm{Ah}}{\mathrm{K}_{\mathrm{B}} \mathrm{T}_{\mathrm{s}}}\right)
\end{gathered}
$$

Where $K_{\mathrm{B}}$ is the Boltzmann constant, $\mathrm{h}$ is the Plank's constant and $T_{\mathrm{s}}$ is the DTG peak temperature.

and Horowitz-Metzger (HM) relationship [29]:

$$
\log \left[\log \left(\frac{w_{\alpha}}{w_{\gamma}}\right)\right]=\frac{\mathbf{E}^{*} \boldsymbol{\theta}}{2.303 R T_{s}^{2}}-\log 2.303
$$

Where $\theta=T-T_{\mathrm{s}}, w_{\gamma}=w_{\alpha}-w, w_{\alpha}=$ mass loss at the completion of the reaction; $w=$ mass loss up to time t. The plot of $\log \left[\log \left(w_{\alpha} / w_{\gamma}\right)\right]$ versus $\theta$ was drawn and found to be linear from the slope of which $\mathrm{E}^{*}$ was calculated. The pre-exponential factor, $\mathrm{A}$, was calculated from the equation:

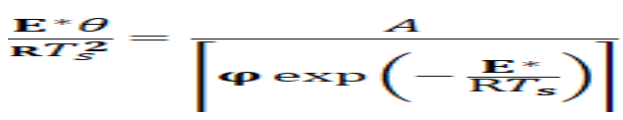

The kinetic parameters were evaluated using the above mentioned methods by graphical means and they are listed in Table 2. The activation energies of decomposition were found to be in the range 11.9- $137.97 \mathrm{~kJ} \mathrm{~mol}^{-1}$. The high values of the activation energies reflect the thermal stability of the complexes. The entropy of activation was found to have negative values in all complexes which indicate that the decomposition reactions proceeded with a lower rate than the normal ones and activated complexes have more ordered systems than reactants [27].

\section{Antibacterial investigation}

The biological activity of LFX and $\mathrm{Zr}(\mathrm{IV})$ complexes were tested against three Gramnegative bacteria and three Gram-positive bacteria, because these microorganisms can get resistance to antibiotics and their metal complexes through biochemical and morphological modifications [30].The results of the antibacterial study of the synthesized complexes and lomefloxacinare displayed in Table 3 and Fig. 3. Surprising [ $\left.\mathrm{ZrO}(\mathrm{LFX})_{2} \mathrm{An}\right]$ $\mathrm{Cl}_{2}$ and $\left[\mathrm{ZrO}(\mathrm{LFX})_{2} \mathrm{O}-\mathrm{Tol}\right] \mathrm{Cl}_{2}$ complexes showed excellent activity against tested samples studied of different bacterial species, (Gramnegative and Gram-positive bacteria).

The enhanced intrinsic activity of complexes can be explained on the basis of cell permeability, the lipid membrane around the cell favors the penetration of lipid-soluble materials; liposolubility is an important factor that controls the antimicrobial activity. On complexation the polarity of the metal ion will be reduced due to overlap of ligand orbital and partial sharing of the positive charge of the metal ions with donor groups [30, 31]. It is likely that the increased liposolubility of the ligand upon metal chelation may contribute to its facile transport into the bacterial cell which blocks the metal binding sites in enzymes of microorganisms [32]. 
TABLE 2. Thermal behavior and kinetic parameters determined using the Coats-Redfern (CR) and HorowitzMetzger (HM) operated for Lomefloxacin and their complexes.

\begin{tabular}{|c|c|c|c|c|c|c|c|c|c|c|}
\hline \multirow[b]{2}{*}{ Compounds } & \multirow[b]{2}{*}{$\begin{array}{c}\text { Decomposition } \\
\text { Range (K) }\end{array}$} & \multirow[b]{2}{*}{$\begin{array}{l}\mathbf{T}_{\mathrm{s}} \\
(\mathbf{K})\end{array}$} & \multirow[b]{2}{*}{ Method } & \multicolumn{5}{|c|}{ Parameter } & \multirow[b]{2}{*}{$\mathbf{R}^{\mathbf{a}}$} & \multirow[b]{2}{*}{$\mathbf{S D}^{\mathbf{b}}$} \\
\hline & & & & $\begin{array}{c}\mathbf{E}^{*} \\
(\mathbf{k J} \\
\left.\mathbf{m o l}^{-1}\right)\end{array}$ & $\underset{\left(s^{-1}\right)}{A}$ & $\begin{array}{c}\Delta \mathbf{S}^{*} \\
\left(\mathbf{J} \mathbf{m o l}^{-1}\right. \\
\left.\mathbf{K}^{-1}\right)\end{array}$ & $\begin{array}{c}\Delta \mathbf{H}^{*} \\
(\mathbf{k J} \\
\left.\mathbf{m o l}^{-1}\right)\end{array}$ & $\begin{array}{c}\Delta \mathbf{G}^{*} \\
(\mathbf{k J} \\
\mathbf{m o l}^{-1)}\end{array}$ & & \\
\hline \multirow{2}{*}{ LFX } & $523-673$ & 592 & $\begin{array}{l}\text { CR } \\
\mathrm{HM}\end{array}$ & $\begin{array}{l}137.71 \\
137.97\end{array}$ & $\begin{array}{l}1.24210^{11} \\
3.33 \times 10^{11}\end{array}$ & $\begin{array}{l}-38.23 \\
-30.03\end{array}$ & $\begin{array}{l}132.79 \\
133.04\end{array}$ & $\begin{array}{l}155.42 \\
150.82\end{array}$ & $\begin{array}{l}0.88 \\
0.87\end{array}$ & $\begin{array}{l}0.33 \\
0.16\end{array}$ \\
\hline & $703-873$ & 695 & $\begin{array}{l}\text { CR } \\
\mathrm{HM}\end{array}$ & $\begin{array}{l}114.12 \\
102.66\end{array}$ & $\begin{array}{l}6.73 \times 10^{4} \\
6.27 \times 10^{6}\end{array}$ & $\begin{array}{l}-159.52 \\
-121.82\end{array}$ & $\begin{array}{c}108.34 \\
96.88\end{array}$ & $\begin{array}{l}219.21 \\
181.55\end{array}$ & $\begin{array}{l}0.97 \\
0.98\end{array}$ & $\begin{array}{l}0.17 \\
0.05\end{array}$ \\
\hline \multirow{2}{*}{$\begin{array}{l}{\left[\mathrm{ZrO}(\mathrm{LFX})_{2}\right.} \\
\mathrm{DMF} \mathrm{Cl}_{2}\end{array}$} & $290-523$ & 411 & $\begin{array}{l}\text { CR } \\
\mathrm{HM} \\
\end{array}$ & $\begin{array}{l}11.9 \\
32.3 \\
\end{array}$ & $\begin{array}{l}1.10 \\
1.63 \\
\end{array}$ & $\begin{array}{l}-247 \\
-247 \\
\end{array}$ & $\begin{array}{c}8.5 \\
28.9\end{array}$ & $\begin{array}{l}110 \\
130 \\
\end{array}$ & $\begin{array}{l}0.92 \\
0.96\end{array}$ & $\begin{array}{l}0.13 \\
0.05\end{array}$ \\
\hline & $523-853$ & 575 & $\begin{array}{l}\text { CR } \\
\mathrm{HM}\end{array}$ & $\begin{array}{l}29.3 \\
28.5\end{array}$ & $\begin{array}{c}3.74 \\
18.99\end{array}$ & $\begin{array}{l}-239 \\
-226\end{array}$ & $\begin{array}{l}24.5 \\
23.7\end{array}$ & $\begin{array}{l}162 \\
154\end{array}$ & $\begin{array}{l}0.94 \\
0.98\end{array}$ & $\begin{array}{l}0.16 \\
0.06\end{array}$ \\
\hline \multirow{2}{*}{$\begin{array}{l}{\left[\mathrm{ZrO}(\mathrm{LFX})_{2}\right.} \\
\mathrm{An}] \mathrm{Cl}_{2}\end{array}$} & $298-462$ & 418 & $\begin{array}{l}\text { CR } \\
\mathrm{HM}\end{array}$ & $\begin{array}{l}25.7 \\
40.2\end{array}$ & $\begin{array}{l}3.07 \times 10^{2} \\
1.38 \times 10^{4}\end{array}$ & $\begin{array}{l}-2.0 \\
-168\end{array}$ & $\begin{array}{l}22.2 \\
36.7\end{array}$ & $\begin{array}{c}106 \\
37\end{array}$ & $\begin{array}{l}0.98 \\
0.98\end{array}$ & $\begin{array}{l}0.11 \\
0.08\end{array}$ \\
\hline & $462-873$ & 561 & $\begin{array}{l}\text { CR } \\
\mathrm{HM}\end{array}$ & $\begin{array}{l}29.0 \\
29.5\end{array}$ & $\begin{array}{l}4.85 \\
0.10\end{array}$ & $\begin{array}{l}-237 \\
-269 \\
\end{array}$ & $\begin{array}{l}24.3 \\
24.8\end{array}$ & $\begin{array}{l}157 \\
176 \\
\end{array}$ & $\begin{array}{l}0.90 \\
0.94 \\
\end{array}$ & $\begin{array}{l}0.29 \\
0.12\end{array}$ \\
\hline \multirow{2}{*}{$\begin{array}{l}{\left[\mathrm{ZrO}(\mathrm{LFX})_{2}\right.} \\
\mathrm{Py}_{\mathrm{Cl}}{ }_{2}\end{array}$} & $308-503$ & 471 & $\begin{array}{l}\text { CR } \\
\mathrm{HM}\end{array}$ & $\begin{array}{l}30.9 \\
59.5\end{array}$ & $\begin{array}{l}9.65 \times 10^{3} \\
6.04 \times 10^{5}\end{array}$ & $\begin{array}{c}-172.4 \\
-138\end{array}$ & $\begin{array}{l}35.1 \\
55.6\end{array}$ & $\begin{array}{l}116 \\
121\end{array}$ & $\begin{array}{l}0.94 \\
0.94\end{array}$ & $\begin{array}{c}0.2 \\
012\end{array}$ \\
\hline & $503-823$ & 636 & $\begin{array}{l}\text { CR } \\
\mathrm{HM}\end{array}$ & $\begin{array}{l}55.6 \\
69.7\end{array}$ & $\begin{array}{l}2.78 \times 10^{3} \\
5.19 \times 10^{4}\end{array}$ & $\begin{array}{l}-185 \\
-161\end{array}$ & $\begin{array}{l}50.3 \\
64.4\end{array}$ & $\begin{array}{l}168 \\
167\end{array}$ & $\begin{array}{l}0.98 \\
0.98\end{array}$ & $\begin{array}{l}0.14 \\
0.06\end{array}$ \\
\hline $\begin{array}{l}{\left[\mathrm{ZrO}(\mathrm{LFX})_{2}\right.} \\
\mathrm{o}-\mathrm{Tol}] \mathrm{Cl}_{2}\end{array}$ & $523-823$ & 564 & $\begin{array}{l}\text { CR } \\
\mathrm{HM}\end{array}$ & $\begin{array}{l}22.0 \\
24.4\end{array}$ & $\begin{array}{l}0.94 \\
7.9\end{array}$ & $\begin{array}{l}-251 \\
-233\end{array}$ & $\begin{array}{l}17.3 \\
19.7\end{array}$ & $\begin{array}{l}159 \\
151\end{array}$ & $\begin{array}{l}0.92 \\
0.96\end{array}$ & $\begin{array}{l}0.17 \\
0.08\end{array}$ \\
\hline
\end{tabular}

$a=$ correlation coefficients of the Arrhenius plots and $b=$ standard deviation.

TABLE 3. The inhibitation diameter zone values ( $\mathrm{mm}$ ) for LFX and its $\operatorname{Zr}(\mathrm{IV})$ complexes.

\begin{tabular}{|c|c|c|c|c|c|c|c|}
\hline \multirow{2}{*}{\multicolumn{2}{|c|}{ Compounds }} & \multicolumn{6}{|c|}{ Microbial Bacteria species } \\
\hline & & K.pneumoniae & $\begin{array}{c}P . \\
\text { aeruginosa }\end{array}$ & B. subtilis & S. pyogenes & S. aureus & \\
\hline \multicolumn{2}{|l|}{ LFX } & $\begin{array}{c}11.9 \\
\pm 0.25\end{array}$ & $\begin{array}{c}13.8 \\
\pm 0.19\end{array}$ & $\begin{array}{c}12.5 \\
\pm 0.19\end{array}$ & $\begin{array}{c}16.9 \\
\pm 0.25\end{array}$ & $\begin{array}{c}18.4 \\
\pm 0.44\end{array}$ & $\begin{array}{c}19.8 \\
\pm 0.44\end{array}$ \\
\hline \multicolumn{2}{|c|}{$\mathrm{Zr}(\mathrm{IV}) / \mathrm{LFX} / \mathrm{DMF}$} & $\begin{array}{c}13.2^{\mathrm{NS}} \\
\pm 0.3\end{array}$ & $\begin{array}{c}14.6^{+1} \\
\pm 0.4\end{array}$ & $\begin{array}{c}13.8^{+1} \\
\pm 0.3\end{array}$ & $\begin{array}{c}18.1^{+1} \\
\pm 0.3\end{array}$ & $\begin{array}{c}20.5^{+1} \\
\pm 0.4\end{array}$ & $\begin{array}{c}21.3^{+1} \\
\pm 0.3\end{array}$ \\
\hline \multicolumn{2}{|c|}{$\mathrm{Zr}(\mathrm{IV}) / \mathrm{LFX} / \mathrm{An}$} & $\begin{array}{c}18.7^{+1} \\
\pm 0.4\end{array}$ & $\begin{array}{c}20.1^{+2} \\
\pm 0.2\end{array}$ & $\begin{array}{l}19.1^{+1} \\
\pm 0.1\end{array}$ & $\begin{array}{c}22.9^{+1} \\
\pm 0.4\end{array}$ & $\begin{array}{c}26.8^{+1} \\
\pm 0.3\end{array}$ & $\begin{array}{c}25.5^{+1} \\
\pm 0.4\end{array}$ \\
\hline \multicolumn{2}{|c|}{$\mathrm{Zr}$ (IV) / LFX /Py } & $\begin{array}{c}16.2^{+1} \\
\pm 0.4\end{array}$ & $\begin{array}{c}18.4^{+1} \\
\pm 0.3\end{array}$ & $\begin{array}{l}17.8^{+1} \\
\pm 0.3\end{array}$ & $\begin{array}{c}21.4^{+1} \\
\pm 0.3\end{array}$ & $\begin{array}{c}24.7^{+1} \\
\pm 0.3\end{array}$ & $\begin{array}{c}22.2^{+1} \\
\pm 0.4\end{array}$ \\
\hline \multicolumn{2}{|c|}{$\mathrm{Zr}$ (IV) / LFX / o-Tol } & $\begin{array}{c}21.2^{+2} \\
\pm 0.4\end{array}$ & $\begin{array}{c}28.1^{+3} \\
\pm 0.4\end{array}$ & $\begin{array}{c}27.6^{+3} \\
\pm 0.3\end{array}$ & $\begin{array}{c}28.9^{+3} \\
\pm 0.4\end{array}$ & $\begin{array}{c}34.9^{+3} \\
\pm 0.2\end{array}$ & $\begin{array}{c}35.8^{+3} \\
\pm 0.4\end{array}$ \\
\hline \multicolumn{2}{|c|}{$\mathrm{ZrOCl}_{2} \cdot 6 \mathrm{H}_{2} \mathrm{O}$} & 0 & 0 & 0 & 0 & 0 & 0 \\
\hline \multicolumn{2}{|c|}{ Control (DMSO) } & 0 & 0 & 0 & 0 & 0 & 0 \\
\hline \multirow{2}{*}{ Standard } & Penicillin G & $\begin{array}{c}15.1 \\
\pm 0.07\end{array}$ & $\begin{array}{c}16.2 \\
\pm 0.09\end{array}$ & $\begin{array}{c}17.0 \\
\pm 0.05\end{array}$ & $\begin{array}{c}21.5 \\
\pm 0.06\end{array}$ & $\begin{array}{l}20.3 \\
\pm 0.2\end{array}$ & $\begin{array}{c}19.4 \\
\pm 0.08\end{array}$ \\
\hline & Streptomycin & $\begin{array}{c}16.6 \\
\pm 0.04\end{array}$ & $\begin{array}{c}17.6 \\
\pm 0.09\end{array}$ & $\begin{array}{c}15.3 \\
\pm 0.08\end{array}$ & $\begin{array}{c}17.1 \\
\pm 0.04\end{array}$ & $\begin{array}{l}21.3 \\
\pm 0.2\end{array}$ & $\begin{array}{c}18.1 \\
\pm 0.08\end{array}$ \\
\hline
\end{tabular}

Statistical significance ${ }^{(N S)}$ not significance, $\mathrm{p}>0.05 ;^{(+1)}$ significant, $\mathrm{p}<0.05 ;^{(+2)}$ highly significant, $\mathrm{p}<0.01 ;^{(+3)}$ very highly significant, $\mathrm{p}<0.001$; student's t-test.data are expressed in the form of mean $\pm \mathrm{SD}$. 


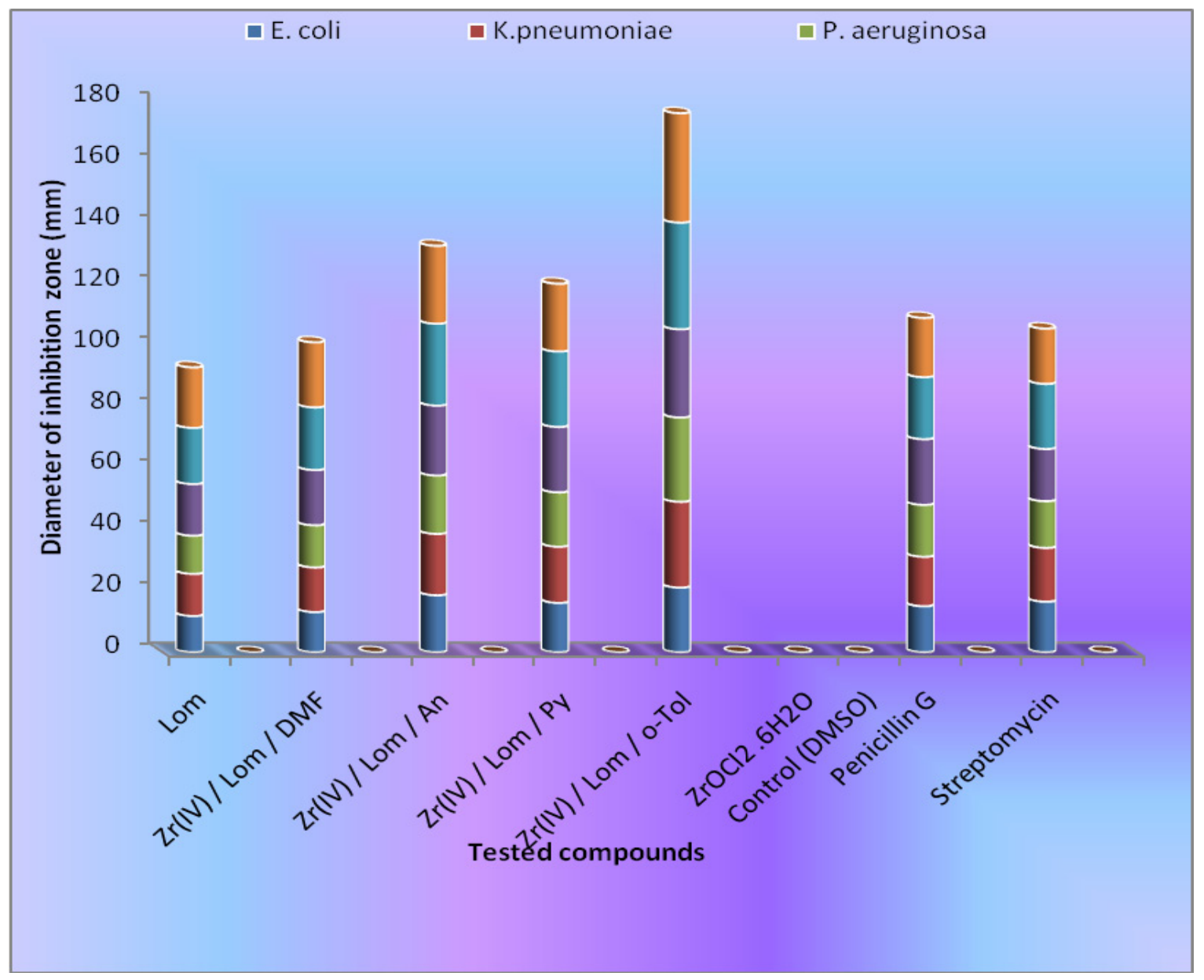

Fig. 3. Statistical representation for biological activity of lomfloxacin and its complexes.

\section{Conclusion}

The coordination ability of (LFX) ligand in complexation reaction with $\mathrm{Zr}(\mathrm{IV})$ in presence of aniline (An), pyridine (Py) and o-tolidine (o-Tol) as nitrogen donor molecules and dimethyl formamide (DMF) as oxygen donor were explained by micro-analytical analyses, spectroscopic tools (e.g., IR, UV-Vis. and ${ }^{1} \mathrm{H}$ NMR) and thermal analysis. The values of molar conductance for the complexes dissolved in dimethylsulfoxide led to electrolytic behavior. The present study confirmed octahedral geometries around metal complexes with the bidentate ligands. Thermal studies of the compounds suggest that the complexes are more stable than the free ligands. This fact was supported with the kinetic parameters $E^{*}, \Delta S^{*}$, $\Delta \mathrm{H}^{*}$ and $\Delta \mathrm{G}^{*}$ suggest more ordered activated state in complex formation. The results of the Antibacterial screening of the ligands and their metal complexes reveal that the Surprising
$\left[\mathrm{ZrO}(\mathrm{LFX})_{2} \mathrm{An}\right] \mathrm{Cl}_{2}$ and $\left[\mathrm{ZrO}(\mathrm{LFX})_{2} \mathrm{o}-\mathrm{Tol}\right] \mathrm{Cl}_{2}$ complexes showed excellent activity against tested samples studied of different bacterial species, (Gram-negative and Gram-positive bacteria).

\section{References}

1. Wallis S.C., Gahan L.R., Charles B.G. and Hambley T.W., ${ }^{13} \mathrm{C}$ N.M.R. and SingleCrystal X-Ray Structural Investigation of the Fluoroquinolone Antimicrobial Drug Norfloxacin 2DCl.D 2 O, Aust. J. Chem., 47, 799 (1994).

2. Turel I. and Bukovec P., Comparison of the thermal stability of ciprofloxacin and its compounds, Thermochim. Acta, 287, 311 (1996).

3. Czugler M., Argay G., Frank J., Meśzaŕos Z., Kutschabsky L. and Reck G., 1-Ethyl-1,4dihydro-4-oxo-5-amino-6,7-methylenedioxy-3quinolinecarboxylic acid (aminooxolinic acid), Acta Crystallogr. B32, 3124 (1976). 
4. Cygler M. and Huber C.P., Structure of oxolinic acid, a potent antibacterial agent. 1-Ethyl1,4-di-hydro-6,7-methylene-dioxy-4-oxo-3quinoline-carboxylic acid, $\mathrm{C}_{13} \mathrm{H}_{11} \mathrm{NO}_{5}$, Acta Crystallogr. C 41, 1052 (1985).

5. Zordok, W.A., Interaction of vanadium (IV) solvates (L) with second-generation fluoroquinolone antibacterial drug ciprofloxacin: spectroscopic, structure, thermal analyses, kinetics and biological evaluation $(\mathrm{L}=\mathrm{An}, \mathrm{DMF}, \mathrm{Py}$ and Et3N)., Spectrochim. Acta A,129C, 519 (2014).

6. Zordok, W.A., Synthesis, spectroscopic, structural characterization, thermal analysis, kinetics, biological evaluation of non-steroidal antiinflammatory drug diclofenac zirconium (IV) solvates (L) (L = H 2 O, DMF, Py and Et 3 N), J. Mol. Struct., 1166, 270 (2018).

7. Florence A.J., Kennedy A.R., Shankland N., Wright E. and Al Rubayi A., Norfloxacin dehydrate, Acta Crystallogr. C 56, 1372 (2000).

8. Turel I., Bukovec P. and Quiros M., Gel Growth, XRD, SEM and Spectral Studies of Ciprofloxacin Hexa-hydrate, Int. J. Pharm. 152, 59 (1997).

9. Sivalakshmidevi A., Vyas K. and Om Reddy G., Sparfloxacin, an antibacterial drug, Acta Crystallogr. C 56, e115 (2000).

10. Ruiz M., Perellò L., Ortiz R., Castiñeiras A., Maichle-Mösser C. and Cantòn E., Synthesis, characterization, and crystal structure of $\left.[\mathrm{Cu} \text { (cinoxacinate })_{2}\right]$. 2 $\mathrm{H}_{2} \mathrm{O}$ complex: A squareplanar $\mathrm{CuO}_{4}$ chromophore. Antibacterial studies, J. Inorg. Biochem. 59, 801 (1995).

11. Chen Z.F., Xiong R.J.J., Zuo L., Guo Z., You X.Z. and Fun K.H., Magnesium, calcium and barium perchlorate complexes of ciprofloxacin and norfloxacin, J. Chem. Soc. Dalton Trans. 22, $4013(2000)$.

12. Ruiz M., Ortiz R., Perellò L. and Carrio J.S., Potentiometric and spectroscopic studies of transition-metal ions complexes with a quinolone derivative (cinoxacin). Crystal structures of new $\mathrm{Cu}(\mathrm{II})$ and $\mathrm{Ni}(\mathrm{II})$ cinoxacin complexes, J. Inorg. Biochem. 65, 87 (1997).

13. Macias B., Villa M.V., Rubio I. and A. Castineiras, Copper complexes with dithiocarbamates derived from natural occurring amino acids. Crystal and molecular structure of $[\mathrm{Cu}(\mathrm{en})(\mathrm{EtOH})(\mathrm{H} 2 \mathrm{O}) 3]$ [Cu (dtc-pro) 2], J. Inorg. Biochem. 65, 163 (1997).
14. I Turel., Leban I. and Bukovec N., Crystal structure and characterization of the bismuth(III) compound with quinolone family member (ciprofloxacin). Antibacterial study, J. Inorg. Biochem. 66, 241 (1997).

15. Abd El-Halim H.F., Mohamed G.G., ElDessouky M.M.I. and Mahmoud W.H., Ligational behaviour of lomefloxacin drug towards $\mathrm{Cr}(\mathrm{III})$, $\mathrm{Mn}(\mathrm{II}), \mathrm{Fe}(\mathrm{III}), \mathrm{Co}(\mathrm{II}), \mathrm{Ni}(\mathrm{II}), \mathrm{Cu}(\mathrm{II}), \mathrm{Zn}(\mathrm{II})$, Th(IV) and UO(2)(VI) ions: synthesis, structural characterization and biological activity studies, Spectrochim. Acta A, 82, 8 (2011).

16. Vieira L.M.M., De Almeida M.V., Maria C.S.L., Flávio A.F.M. and Fontes A.P.S., Trisulfonated Porphyrazines: New Photosensitizers for the Treatment of Retinal and Subretinal Edema, $J$. Med. Chem. 44, 4107 (2009).

17. Sultana N., Arayne M.S., Rizvi S.B.S., Haroon U. and Mesaik M.A., Synthesis, Spectroscopic and Biological Evaluation of some Levofloxacin Metal Complexes, Med. Chem. Res. 22, 1371 (2012).

18. Komarnicka U.K., Starosta R., Kyzioł A., Płotek M., Puchalska M. and Jeżowska-Bojczuk M., New copper(I) complexes bearing lomefloxacin motif: Spectroscopic properties, in vitro cytotoxicity and interactions with DNA and human serum albumin, J. Inorg. Biochem. 165, 25 (2016).

19. Ragheb M.A., Eldesouki M.A. and Mohamed M.S., Synthesis, DNA interactions and antibacterial PDT of $\mathrm{Cu}(\mathrm{II})$ complexes of phenanthroline based photosensitizers via singlet oxygen generation, Spectrochim. Acta A, 138, 585 (2015).

20. Mohamed G.G., Abd El-Halim H.F., El-Dessouky M.M.I. and Mahmoud W.H., Synthesis and characterization of mixed ligand complexes of lomefloxacin drug and glycine with transition metals. Antibacterial, antifungal and cytotoxicity studies, J. Mol. Struct. 999, 29 (2011).

21. Fernandes P., Sousa I., Cunha-Silva L., Ferreira M., de Castro B., Pereira E.F., Feio M.J and Gameiro P., Synthesis, characterization and antibacterial studies of a copper(II) lomefloxacin ternary complex, J. Inorg. Biochem. 131, 21 (2014).

22. Sadeek S.A., El-Shwiniy W.H., El-Attar M.S., Zordok W.A., Spectroscopic, structural and antibacterial evaluation of some lomefloxacin metal complexes, Int. J. Adv. Res. 2, 158 (2014). 
23. Geary W.J., The use of conductivity measurements in organic solvents for the characterisation of coordination compounds, Coord. Chem. Rev., 7, 81 (1971).

24. Wesam S.S., El-Shwiniy W.H., Nanoparticles of manganese oxides as efficient catalyst for the synthesis of pyrano[2,3-d]pyrimidine derivatives and their complexes as potent protease inhibitors, J. Iran. Chem. Soc., 15, 431 ( 2018).

25. Sadeek S.A., Synthesis, thermogravimetric analysis, infrared, electronic and mass spectra of $\mathrm{Mn}(\mathrm{II}), \mathrm{Co}(\mathrm{II})$ and $\mathrm{Fe}(\mathrm{III})$ norfloxacin complexes, J. Mol. Struct. 753, 1 (2005).

26. Sadeek S.A., EL-Shwiniy W.H. and El-Attar M.S., Synthesis, characterization and antimicrobial investigation of some moxifloxacin metal complexes, Spectrochim. Acta A. 84, 99 (2011).

27. Nakamoto, "Infrared and Raman spectra of Inorganic and Coordination Compounds", $4^{\text {th }}$ Ed., Wiely, New York, 230 (1986).

28. Coats A.W., Redfern J.P., Kinetic Parameters from Thermogravimetric Data, Nature, 201, 68 (1964).

29. Horowitz H.W., Metzger G., A New Analysis of Thermogravimetric Traces., Anal. Chem. 35, 1464 (1963).

30. Rehman W., Baloch M.K. and Badshah A., Synthesis Characterization and Biological Screening of Tri-benzyl Tin(IV) Complexes of Some Schiff Bases, J. Med. Chem. 43, 2380 (2008).

31. El-Shwiniy W. H., Zordok W. A., Synthesis, spectral, DFT modeling, cytotoxicity and microbial studies of novel $\mathrm{Zr}(\mathrm{IV}), \mathrm{Ce}(\mathrm{IV})$ and U(VI) piroxicam complexes, Spectrochim. Acta A, 199, 290 (2018).

32. Muhammad I., Javed I., Shahid I. and Nazia I., In Vitro Antibacterial Studies of Ciprofloxacinimines and Their Complexes with $\mathrm{Cu}(\mathrm{II}), \mathrm{Ni}(\mathrm{II})$, Co(II), and Zn(II), Turk. J. Biol., 31, 67 (2007).

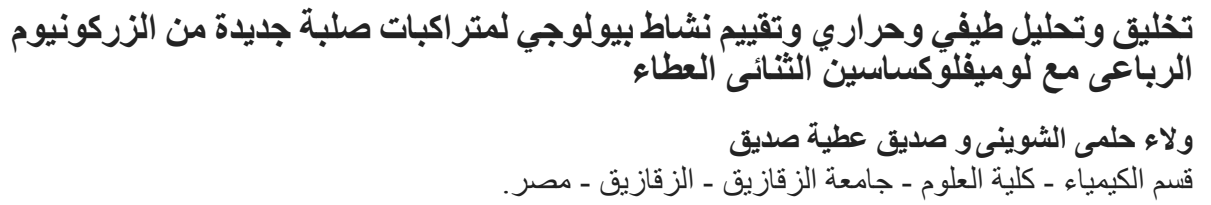

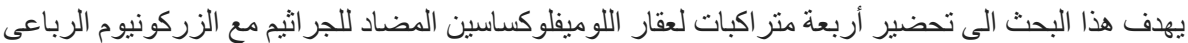

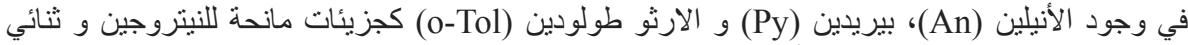

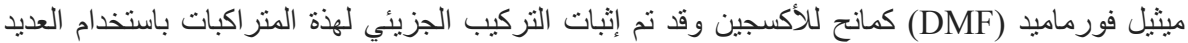

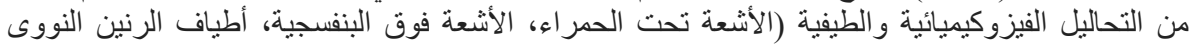

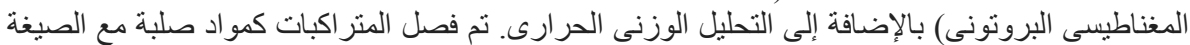

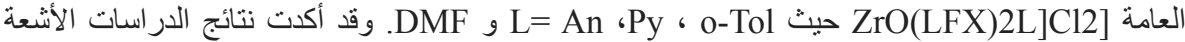

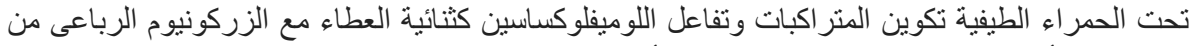

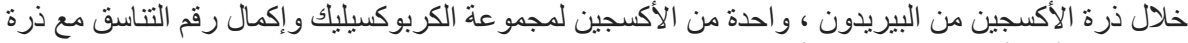

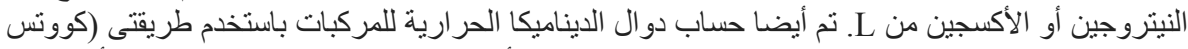

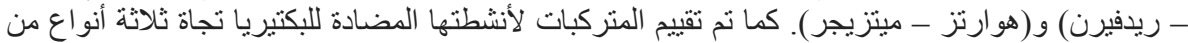

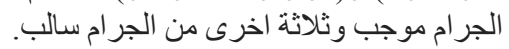

